\title{
IL-17A Induces Pro-Inflammatory Cytokines Production in Macrophages via MAPKinases, NF-kB and AP-1
}

\author{
Jian Chen ${ }^{\mathrm{a}, \mathrm{c}}$ Meng-yang Liao ${ }^{\mathrm{a}, \mathrm{c}}$ Xing-li Gao ${ }^{\mathrm{a}, \mathrm{c}}$ Qi Zhong ${ }^{\mathrm{b}, \mathrm{c}}$ Ting-ting Tang ${ }^{\mathrm{a}}$ \\ Xian Yu ${ }^{a}$ Yu-hua Liao ${ }^{a}$ Xiang Cheng ${ }^{\text {a }}$
}

\begin{abstract}
aLaboratory of Cardiovascular Immunology, Institute of Cardiology, Union Hospital, Tongji Medical College of Huazhong University of Science and Technology, Wuhan; 'Department of Cardiology, Guangdong Cardiovascular Institute, Guangdong General Hospital, Guangdong Academy of Medical Sciences, Guangzhou, China; 'These authors contribute to the work equally
\end{abstract}

\section{Key Words}

Macrophages • Interleukin 17A • Inflammatory cytokines

\begin{abstract}
Background: Interleukin (IL)-17A, a newly identified cytokine, may participate in the transition of a stable plaque into an unstable plaque. Macrophages play a critical role in the destabilization of atherosclerotic plaque. Methods: RAW 264.7 cells were stimulated with IL-17A. The mRNA expression of inflammatory cytokines was determined by RT-PCR. The cytokines production in the supernatants was measured by ELISA. Small interfering RNA (siRNA) was used to confirm that IL-17A-induced pro-inflammatory cytokines production via IL-17RA signaling. The western blot assay was used to detect the phosphorylation of MAPKinases including p38 and ERK1/2. The DNA binding activity of nuclear factor NF-KB and AP-1 were detected by EMSA. Results: IL-17A induced the production of pro-inflammatory cytokines in macrophages in a time- and dose-dependent manner, such as tumor necrosis factor (TNF)- $\alpha$, IL-1 $\beta$, and IL-6. Meanwhile, IL-17A resulted in the phosphorylation of p38 and ERK1/2 and increased DNA-binding activity of NF-KB and AP-1. Pharmacological inhibitors of $\mathrm{p} 38$ and ERK1/2 partly attenuated IL-17A-induced TNF- $\alpha$, IL-1 $\beta$, and IL- 6 production. Either NF-kB inhibitor or AP-1 inhibitor also partly decreased the IL-17A-induced cytokine production. Conclusions: IL-17A induces pro-inflammatory cytokines production in macrophages via MAPKinases, NF-KB and AP-1 pathway.
\end{abstract}

Copyright $\odot 2013$ S. Karger AG, Basel 


\section{Introduction}

The concept that atherosclerosis is a chronic inflammation disease is well accepted [1]. Chronic inflammation in atherosclerosis is characterized by the entry of immune cells into the artery wall and subsequent production of pro-inflammatory cytokines, which contribute to the atherosclerotic plaque formation and progression [2]. Mounting evidence suggests a relationship between inflammation and the plaque destabilization [3], which is a major cause of acute coronary syndrome including unstable angina and myocardial infarction. Interleukin (IL)-17 is a newly identified pro-inflammatory cytokine and play a critical role in many inflammatory diseases, such as rheumatoid arthritis (RA) [4], inflammatory bowel diseases (IBD) [5], viral myocarditis [6], and myocardial ischemia/reperfusion injury [7]. The majority of IL-17 is secreted by T helper (Th) 17 cells [8], a CD4+ T cells subtype distinct from Th1 and Th2 cells.

The IL-17 family is comprised of 6 members, including IL-17A, IL-17B, IL-17C, IL-17D, IL-17E and IL-17F [9]. IL-17A, commonly referred to as IL-17, has been shown to affect plaque stability in both animal and clinical experiments [10-12]. However, the way in which IL-17A may affect the plaque stability is not fully understood. Macrophages, as the most abundant immune cells in all stages of plaques [13], undergoes activation in responses to a variety of pathogenic stimuli (eg, oxidized low-density lipoprotein and interferon- $\gamma$ from $\mathrm{T}$ cells) and produce a pro-inflammatory cytokine response which in turn resulted in destabilization of atherosclerotic plaque. Hence, we postulated that IL-17A may act on macrophages to promote the plaque instability. In this study, we examined the effects of IL$17 \mathrm{~A}$ on pro-inflammatory cytokines production in cultured macrophages and identified the intracellular signaling pathways mediating the effect of IL-17A.

\section{Materials and Methods}

\section{Reagents}

Recombinant mouse IL-17A, as well as IL-1 $\beta$, IL-6, and TNF- $\alpha$ enzyme-linked immunosorbent assay (ELISA) kit were purchased from R\&D systems (Minneapolis, MN). Nuclear factor (NF)- $\kappa B$ Pathway Sampler Kit and mitogen-activated protein kinase (MAPK) Family Antibody Samper Kit were obtained from Cell Signaling Technology (Beverly, MA). U0126, the specific inhibitor of MEK1/2, was from Promega (San Luis Obispo, CA). SB203580, and curcumin, the specific inhibitor of p38 MAPK, and AP-1, were from Alexis Biochemicals (San Diego, CA). The inhibitor of NF- $\kappa B, N$-tosyl phenylalanyl chloromethyl ketone (TPCK), was obtained from Sigma-Aldrich (St. Louis, MO).

Cells

RAW 264.7 cells, a murine macrophages cell line derived from Abelson murine leukemia virus-induced tumor, were obtained from ATCC. Cells were cultured and propagated as previously described [13]. Briefly, RAW 264.7 cells were cultured in DMEM supplemented with $10 \%$ of FCS, 100U/ml penicillin-streptomycin and maintained in a humidified $5 \% \mathrm{CO}_{2}$ incubator at $37^{\circ} \mathrm{C}$. Cells were serum-deprived for $24 \mathrm{~h}$ before the addition of either IL-17A or MAPK inhibitors.

\section{Real-time PCR}

Cells were stimulated with IL-17A (100ng/ml) for a period of time. After the stimulation, total RNA was extracted by Trizol and reverse transcripted into cDNA using PrimeScript RT reagent Kit according to the manufacture's instruction according to manufacturer's protocol. The mRNA expression of target genes were quantified using SYBR Green Master Mix (Takara Biotechnology, Dalian, China) on an ABI PRISM 7900 Sequence Detector system (Applied Biosystem, Foster City, CA). Primer sequences were shown in Table 1. The $\triangle \mathrm{C}_{\mathrm{T}}$ method using GAPDH as the reference gene was used for the relative quantification of target genes. 


\begin{tabular}{|c|c|c|}
\hline Cellular Physiology & Cell Physiol Biochem 2013;32:1265-1274 & \\
\hline and Biochemistry & $\begin{array}{l}\text { DOI: } 10.1159 / 000354525 \\
\text { Publisnea oninne. Tovember } 21,2013\end{array}$ & $\begin{array}{l}\text { O } 2013 \text { S. Karger AG, Basel } \\
\text { www.karger.com/cpb }\end{array}$ \\
\hline
\end{tabular}

Table 1. Primer sequences in RT-PCR

\begin{tabular}{lll}
\hline Genes & Forward $\left(5^{\prime}-3^{\prime}\right)$ & Reverse $\left(5^{\prime}-3^{\prime}\right)$ \\
\hline IL-17RA & CCATCAGCGAGCTAATGTCA & AATGGCGATGAGTGTGATGA \\
IL-17RC & ACACTGCACGCTGCTCTCTA & CGCAATCTGTCTTCTGTGGA \\
TNF- $\alpha$ & CCGGGCAGGTCTACTTT & TTGGACCCTGAGCCATAATC \\
IL-1 $\beta$ & AACCTGCTGGTGTGTGACGTT & CAGCACGAGGCTTTTTTGTTG \\
IL-6 & CTGATGCTGGTGACAACCAC & CATTTCCACGATTTCCCAGA \\
MCP-1 & AGCACCAGCCAACTCTCACT & TCATTGGGATCATCTTGCTG \\
GM-CSF & TGTCTCTGGCTACCCGACTT & GCCTCTACATGCTTCCAAGG \\
MMP-2 & GATAACCTGGATGCCGTCGTG & CTTCACGCTCTTGAGACTTTGGTTC \\
IL-23p19 & CCAGCAGCTCTCTCGGAATC & TCATATGTCCCGCTGGTGC \\
IFN- $\gamma$ & CGGCACAGTCATTGAAAGCCTA & GTTGCTGATGGCCTGATTGTC \\
GAPDH & CAGGTTGTCTCCTGCGACTT & CCCTGTTGCTGTAGCCGTAT \\
\hline
\end{tabular}

ELISA

Cells were stimulated with IL-17A (100ng/ml) for a period of time and the concentrations of IL-1 $\beta$, IL-6, and tumor necrosis factor (TNF)- $\alpha$ in the supernatants were quantified using respective ELISA kits. In some experiments, cells were pretreated with inhibitors of ERK1/2 (U0126, $10 \mu \mathrm{M}$ ), p38 (SB203580, $10 \mu \mathrm{M}$ ), NF- $\mathrm{kB}$ inhibitor (TPCK, $10 \mu \mathrm{M}$ ) and AP-1 inhibitor (curcumin, $10 \mu \mathrm{M}$ ) for 30 minutes before the addition of IL-17A.

Small interfering iRNA (siRNA) transfection

Raw 264.7 cells were seeded in 12 -well plates at $40 \%$ density the day before transfection, medium was exchanged to $800 \mu \mathrm{l}$ Opti-MEM $4 \mathrm{~h}$ before transfection. For each well, $200 \mu \mathrm{l}$ OptiMEM (Life Technologies, Grand Island, NY, USA) was mixed with $2 \mu \mathrm{l}$ LipofectamineTM2000 (Invitrogen, Carlsbad, CA, USA) and 5ul siRNA which was designed and synthesized by Invitrogen according to the manufacturer's recommendations. The transfection mixture incubated at room temperature for $20 \mathrm{~min}$, and then was added to cells. Six hours after transfection, the medium was replaced with fresh medium, and cells were stimulated with IL17A or LPS. Cells were harvested $48 \mathrm{~h}$ after transfection for analysis. The siRNA sequences were as follows: IL17RA: sense 5'- CCU ACG UUG UUU GCU ACU U-3' and antisense 5'- AAG UAG CAA ACA ACG UAG G-3'; the popular type control siRNA was purchased from RiboBio company (Guangzhou, China).

\section{Western blot analysis}

Total protein was extracted from RAW 264.7 cells when they were treated with IL-17A (100ng/ml) for a period of time. Protein sample were then subjected to SDS-PAGE and transferred to a nitrocellulose membrane. The membrane was detected using primary antibodies against phosphorylated ERK1/2, ERK1/2, phosphorylated p38, p38 and $\beta$-actin followed by respective horseradish peroxidase-conjugated secondary antibody. Subsequently, the specific bands were visualized using an enhanced chemiluminescence western blot system. Comparative analysis was performed by quantitative densitometry.

Electrophoretic gel mobility shift assays (EMSA)

Nuclear protein was extracted from RAW 264.7 cells when they were treated with IL-17A (100ng/ $\mathrm{ml}$ ) for a period of time. EMSA was performed using the LightShift Chemiluminescent EMSA kit according to the manufacturer's instruction. Briefly, $15 \mu \mathrm{g}$ nuclear extract was incubated with biotin labeled-probe or unlabeled probe in a final volume of $20 \mu$ binding reaction containing $1 \times$ binding buffer and 1 ug poly (dI$\mathrm{dC}$ ). The probes sequences were as follows: NF- $\mathrm{kB}$ : 5'-biotin-AGT TGA GGG GAC TTT CCC AGC-3' and 5'-AGT TGA GGG GAC TTT CCC AGC-3'; AP-1: 5'-biotin-GTC TAG AGT GAC TCA GCG C-3' and 5'-GTC TAG AGT GAC TCA GCG C-3'. Samples were subjected to $6 \%$ native polyacrylamide gel in a $0.5 \times$ Tris borate-EDTA buffer at $100 \mathrm{~V}$ for $3 \mathrm{hrs}$ and then transferred to nylon membrane in $0.5 \times$ Tris borate-EDTA buffer at $100 \mathrm{~V}$ for 1 hr. After UV crosslink, probed with streptavidin-conjugated HRP and incubated with substrates, the nylon membrane was exposed to X-ray film. Competition EMSA was performed. 


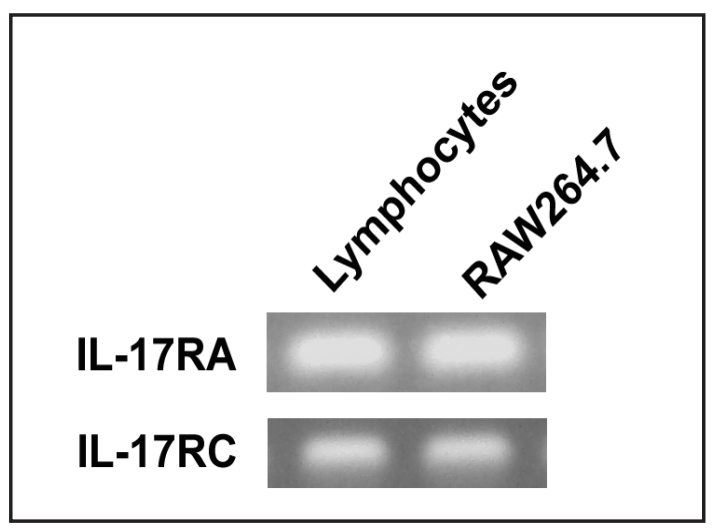

Fig. 1. Expression of IL-17RA and RC in the RAW264.7 cells were detected by RT-PCR and lymphocytes were selected as a positive control.

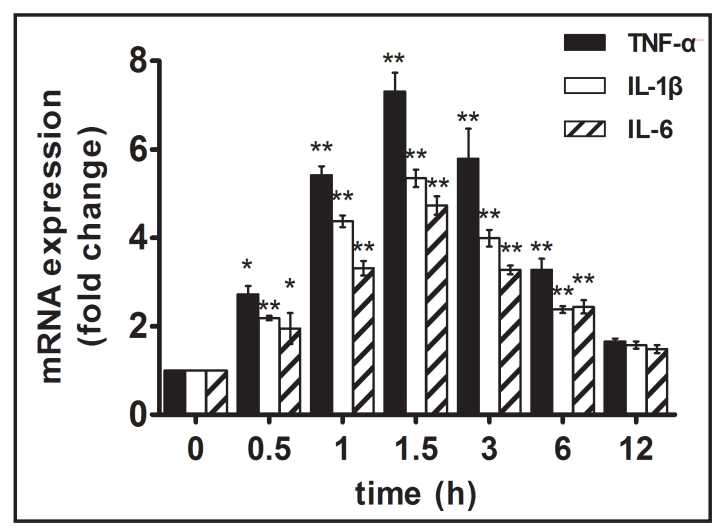

Fig. 2.IL-17A resulted in enhanced mRNA expression of TNF- $\alpha$, IL-1 $\beta$ and IL- 6 in RAW 264.7 cells as determined by RT-PCR. ${ }^{*} p<0.05$ and ${ }^{* *} p<0.01$ vs. 0 h.

Statistics

Results are presented as the mean \pm SEM in the text and figures. Comparison between groups was performed using one-way ANOVA followed by post hoc Bonferroni test when necessary. Statistical significance was set at $p<0.05$.

\section{Results}

\section{IL-17 RA and RC are expressed in macrophages}

With lymphocyte as the positive control, we found that both IL-17 RA and RC were expressed in the murine macrophages cell line RAW264.7 cells as detected by RT-PCR (Fig. 1 ). The results were in according with other studies that showed IL-17RA and RC were expressed in receptor activator of NF- $\mathrm{KB}$ ligand (RANKL)-stimulated RAW264.7 cells and human peripheral blood monocytes $[14,15]$.

$I L-17 A$ resulted in enhanced expression of TNF- $\alpha, I L-1 \beta$, and IL-6 genes in macrophages

We first tried to explore whether IL-17A induced the mRNA expression of inflammatory cytokines or chemokines in RAW 264.7 cells using RT-PCR. RAW267.4 cells were treated with IL-17A (100ng/ml) for a period of time. Enhanced expressions of TNF- $\alpha$, IL-1 $\beta$, and IL- 6 were observed in response to IL-17A. In addition, the three cytokines had the same temporal pattern of expression. After the addition of IL-17A, the expression levels of TNF- $\alpha$, IL- $1 \beta$, and IL- 6 were elevated as early as $0.5 \mathrm{~h}$ and continued to rise, reached the maximum at $1.5 \mathrm{~h}$ and gradually returned back to the baselines at $12 \mathrm{~h}$ (Fig. 2). In contrast, there were no changes in the expression of MCP-1, GM-CSF, MMP-2, IL-23p19, and IFN- $\gamma$ (data not shown).

\section{IL-17A resulted in increased production of TNF- $\alpha, I L-1 \beta$, and IL-6 in macrophages}

Next, we investigated whether increased mRNA expression resulted in increased protein secretion. RAW 264.7 cells were stimulated with gradient concentration of IL-17A for $24 \mathrm{~h}$ before collecting the supernatants and quantifying cytokines by ELISA. As expected, the production of these cytokines was significantly increased by IL-17A in a dose-dependent manner (Fig. 3A). In addition, our data showed that the production of cytokines in RAW267.4 cells was elevated at $6 \mathrm{~h}$ after the addition of IL-17A $(100 \mathrm{ng} / \mathrm{ml})$ and continued to rise thereafter (Fig. 3B).

\section{IL-17A -induced pro-inflammatory cytokines production via IL-17RA signaling}

IL17RA siRNA was used to confirm that IL-17A-induced pro-inflammatory cytokines production via IL-17RA signaling. Firstly, we estimated the effect of the siRNA (Fig. 4A); 


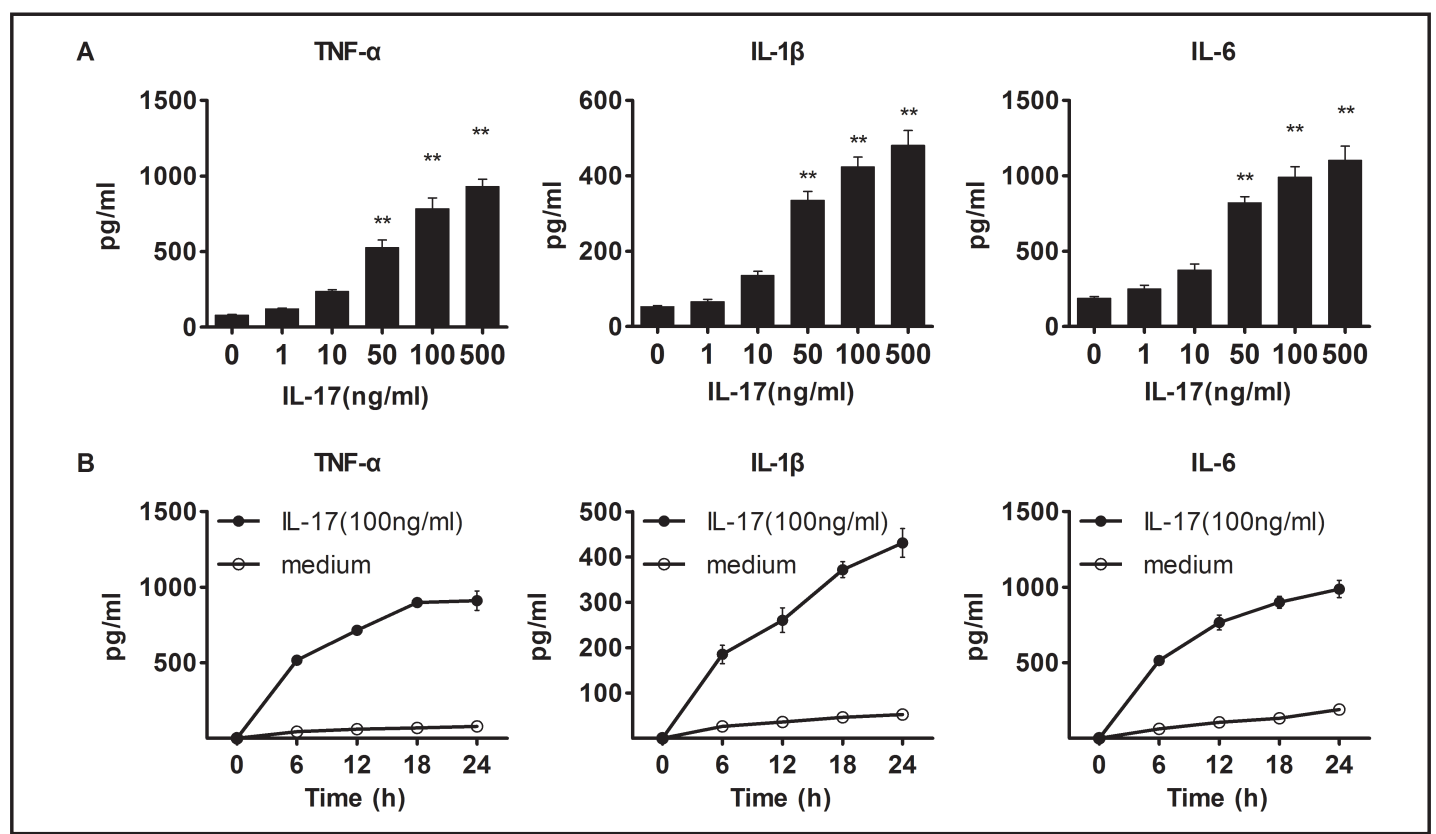

Fig. 3. IL-17A induced a dose- and time-dependent production of TNF- $\alpha$, IL-1 $\beta$ and IL- 6 in RAW 264.7 cells. Cells were stimulated with gradient concentration of IL-17A for $24 \mathrm{~h}(\mathrm{~A})$ or with IL-17A (100ng/ml) for indicated times (B) and the cytokines production of TNF- $\alpha$, IL-1 $\beta$ and IL- 6 were measured by ELISA. ${ }^{* *} p<0.01$ vs. without IL-17A.

Fig. 4. IL-17A-induced pro-inflammatory cytokines production via IL17RA signaling. Cells were transiently transfected with IL17RA siRNA, or Control siRNA(A), the IL17RA mRNA expression levels were detected by real time PCR. The effects of siRNA on IL17A-induced cytokines production in RAW264.7 cells (B,C,D). Cells were pretreated with IL17RA siRNA and then stimulated with IL-17A (100ng/ $\mathrm{ml}) .48 \mathrm{~h}$ later, the total RNA were extracted and the cytokines production of TNF- $\alpha$, IL-1 $\beta$ and IL- 6 were measured by real time PCR. ${ }^{* *} p<0.01$ vs. medium; \# \# $p<0.01$ IL17A stimulated vs. IL17RA siRNA.

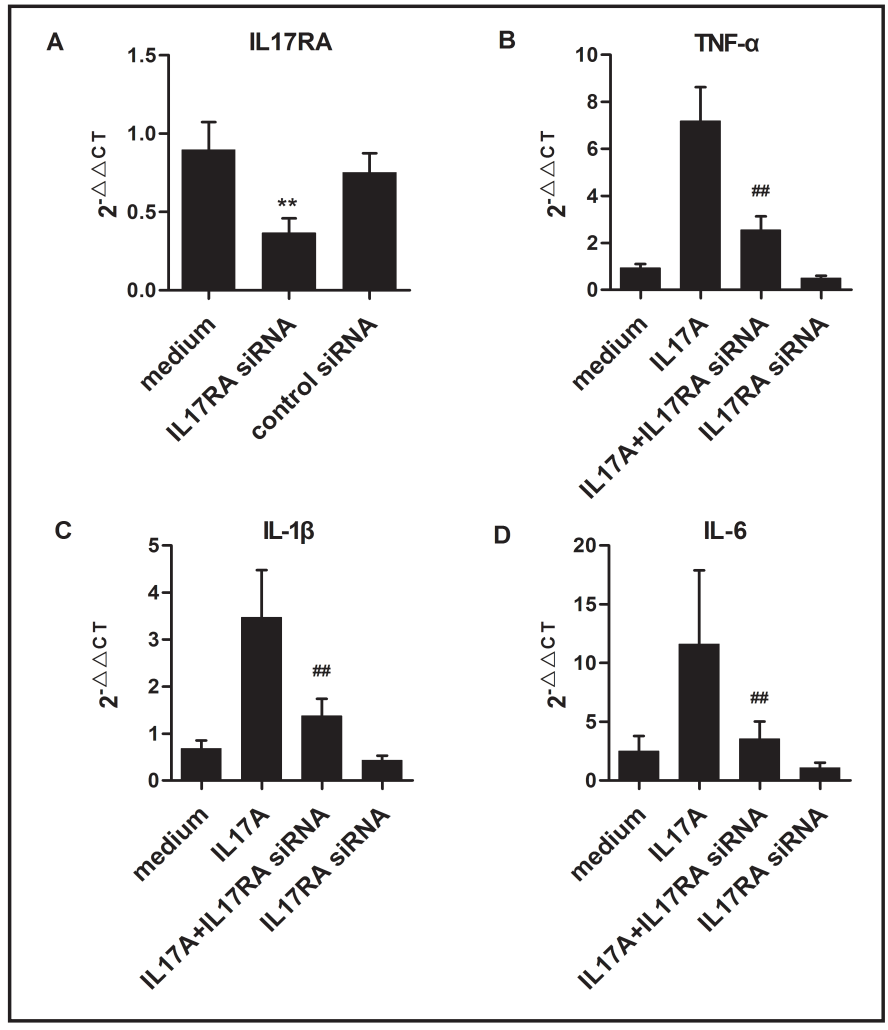

A (c) 2013 S. Karger AG, Basel

www.karger.com/cpb 


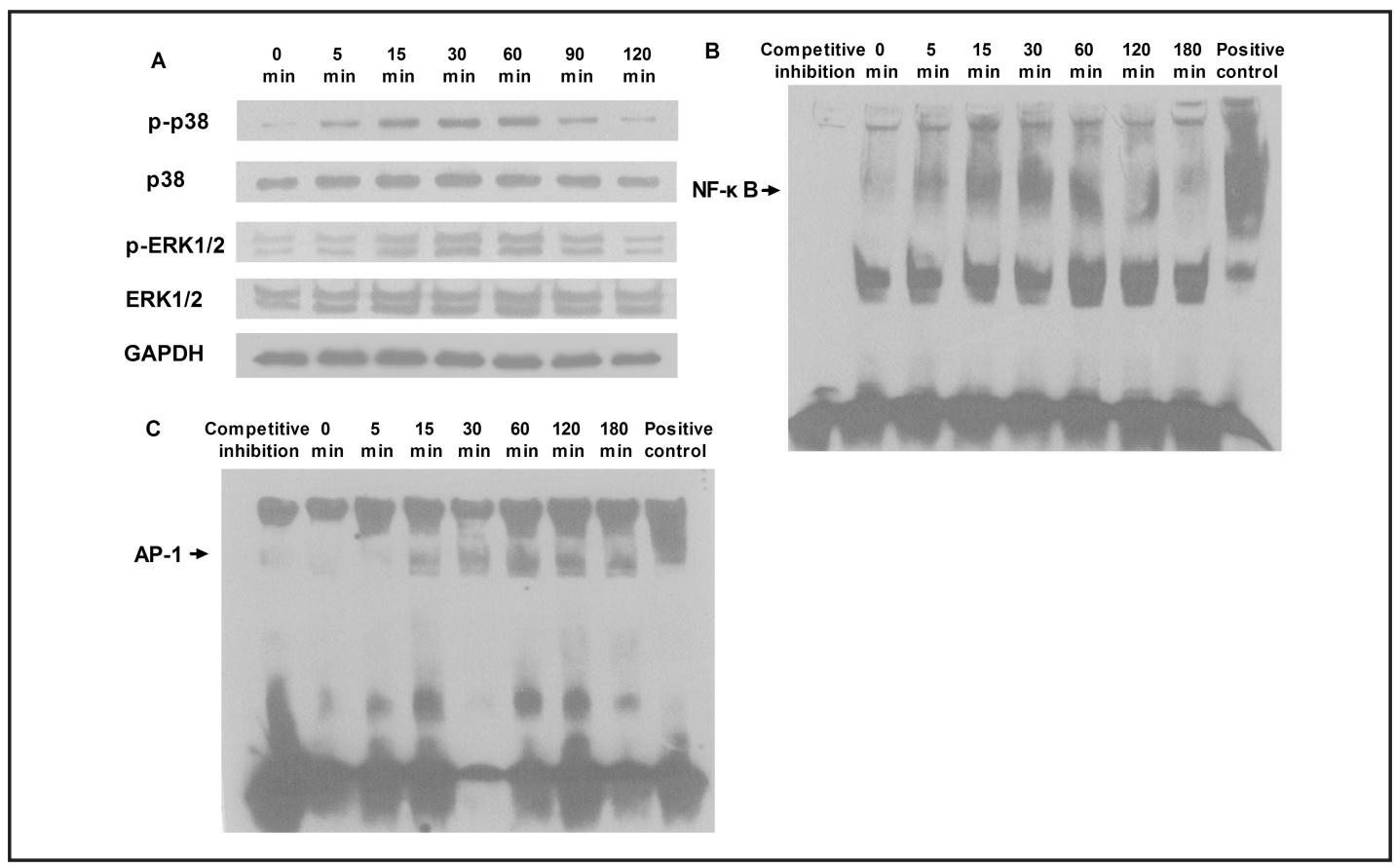

Fig. 5. IL-17A induced a transient phosphorylation of MAPKs and nuclear translocation of NF- $\kappa B$ and AP-1. Cells were stimulated with IL-17A $(100 \mathrm{ng} / \mathrm{ml})$ for indicated times and the total protein or nuclear protein were extracted to detect the phosphorylation of three MAPKs including p38 and ERK1/2 (A) by western blot or the DNA-binding activities of NF- $\kappa \mathrm{B}(\mathrm{B})$ and AP-1 (C) by EMSA respectively.

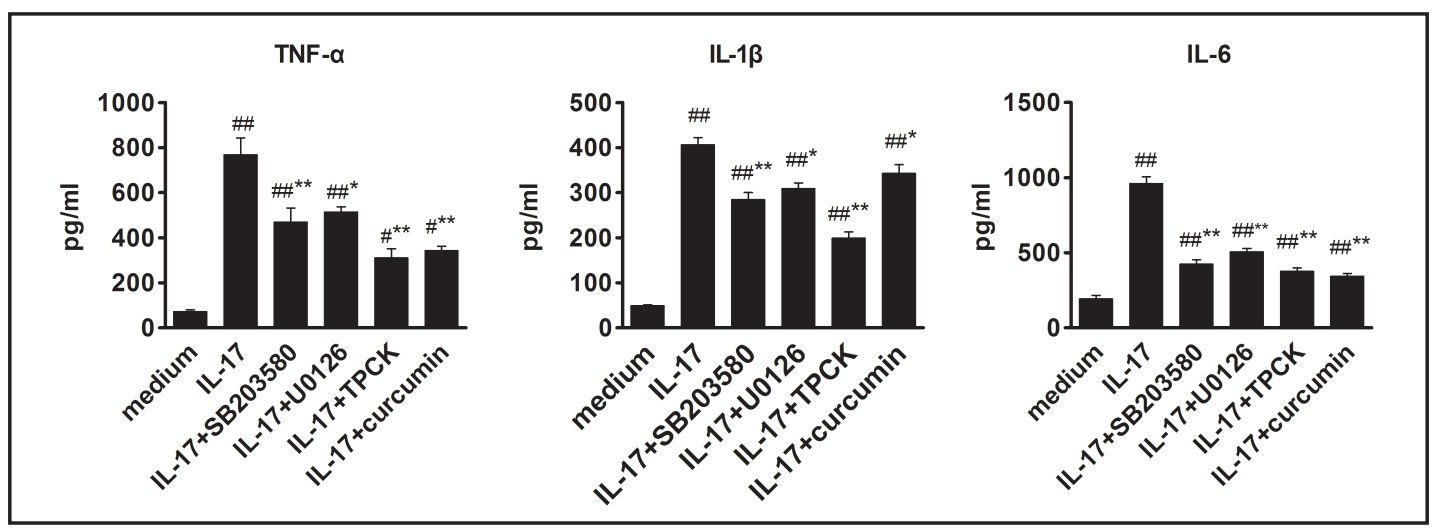

Fig. 6. The effects of signaling inhibitors on IL-17A-induced cytokines production in RAW264.7 cells. Cells were pretreated with inhibitors of signaling pathways including p38 (SB203580), ERK1/2 (U0126), NFКB (TPCK) or AP-1 (curcumin) and then stimulated with IL-17A (100ng/ml). 24h later, the supernatants were collected and the cytokines production of TNF- $\alpha$, IL-1 $\beta$ and IL- 6 were measured by ELISA. ${ }^{*} p<0.05$ and \# \# $p<0.01$ vs. medium; ${ }^{*} p<0.05$ and ${ }^{* *} p<0.01$ vs. IL-17A.

MAPKS, NF- $\kappa B$ and AP-1 signaling pathways were activated by IL-17A in macrophages

As for the mechanism study, we investigated the role of MAPKs (p38 and ERK1/2), NF$\kappa \mathrm{B}$ and AP-1 pathways in IL-17A induced pro-inflammatory cytokine production. Analysis of the time course of the IL-17A response revealed different temporal activation profile for these signaling pathways. The enhanced phosphorylation of $\mathrm{p} 38$ and ERK1/2 were present as early as $5 \mathrm{~min}$ and sustained until $120 \mathrm{~min}$ (Fig. 5A). The enhanced DNA binding activity of $\mathrm{NF}-\mathrm{\kappa B}$ were observed at $5 \mathrm{~min}$, peaked at $30 \mathrm{~min}$ and then rapidly declined to the baseline at 180 min (Fig. 5B). The enhanced DNA binding activity of AP-1 became visible at 15 minutes 
after IL-17A incubation, and was further enhanced to the peak level at $60 \mathrm{~min}$, and was continuously activated $180 \mathrm{~min}$ (Fig. 5C).

IL-17A-induced cytokine production is inhibited by chemical inhibition of MAPK, NF- $\kappa B$ and $A P-1$

We then employed pharmacological signaling inhibitors to confirm the role of these signaling pathways in IL-17A induced cytokine production. The concentration of inhibitors used in our study was first proved to effective and selective inhibit relevant pathways (data not shown). All inhibitors had no effect on the basal levels of cytokine production, where they all partly attenuated IL-17A-induced TNF- $\alpha$, IL-1 $\beta$ and IL-6 production (Fig. 6).

\section{Discussion}

Atherosclerosis is now recognized as an inflammatory disease. Atherosclerotic plaques contain a variety of blood-borne immune cells, including $\mathrm{T}$ lymphocytes, macrophages, dendritic cells, mast cells, a few B cells [16]. T lymphocytes and macrophages are two among many of them and are actively involved in atherogenesis. T cells infiltrating into atherosclerotic plaque are capable of secreting cytokines and chemokines that further activate cells within plaque in autocrine and/or paracrine manners in the whole pathogenesis of atherosclerosis, thus initiate and maintain the inflammatory milieu [17]. CD $4^{+} \mathrm{T}$ cells are the major T-cell lineage in atherosclerotic plaques in both $\mathrm{Apoe}^{-/}$and $\mathrm{Ldlr}^{/-}$mice and adoptive transfer of $\mathrm{CD}^{+} \mathrm{T}$ cells to immune-deficient scid/scid mice aggravates atherosclerosis $[18,19]$. Upon activation, naïve CD4+ T cells differentiate into at least four $\mathrm{CD} 4^{+} \mathrm{T}$ subsets: $\mathrm{T}$ helper $(\mathrm{h}) 1$ cells, Th2 cells, regulatory T (Treg) cells and Th17 cells. Th1 cells aggravate atherosclerosis, whereas Th2 cells and Treg cells confer atheroprotection effect [20]. Recently, there are several lines of evidence that link IL-17A with the development of atherosclerosis. In human coronary plaque, IL-17A and IFN- $\gamma$ were co-produced by resident $\mathrm{T}$ cells and played a synergistic effect in inducing pro-inflammatory cytokines and chemokines production by cultured human vascular smooth muscle cells [9]. In the animal model, ApoE ${ }^{-/}$mice showed enhanced expression of Th17-related cytokines (IL-17 and IL-6) and transcriptional factor

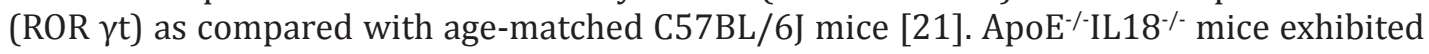
exacerbated plaque formation correlated with increased Th17 cells [22]. However, the precise role of Th17 and IL-17A in atherosclerosis remains to be elucidated. Although there is contradictory evidence of either a decrease [23-25] or no change [12, 26, 27] in plaque area with neutralization of IL-17A, it is now well-established that IL-17A may modulate plaque stability [10-12]. Our previous study has demonstrated an increase in serum level of IL-17 and circulating Th17 frequency in patients with acute coronary syndrome, suggesting that IL-17 might be associated with plaque stability [10]. More recently, direct evidence for IL17 and plaque stability has come from the IL-17\% $\mathrm{ApoE}^{-/}$mice which had reduced vascular inflammation and oxidative stress in comparison with $\mathrm{ApoE}^{-/-}$mice [12].

Macrophages, the immune cells bridging innate immunity and adaptive immunity, are abundant in all stages of atherosclerotic lesions [1]. Macrophages are however heterogeneous cells and when differently activated, they play a pro-atherogenic or an anti-atherogenic role in atherosclerosis [28]. Consistent with previously studies [29, 30], we observed that IL-17A induced production of pro-atherogenic cytokines including TNF- $\alpha$, IL- 6 and IL-1 $\beta$ in macrophages, suggesting that it may enhance plaque instability by prompting a proinflammatory and pro-atherogenic macrophages phenotype.

We further investigated the possible signaling pathways involved in the cytokines response in IL-17A-treated macrophages. MAPKs including p38 and ERK1/2 have been regarded as an important signaling pathway in response to proinflammatory stimuli [31]. In this study, we showed that IL-17A can activate p38 and ERK1/2 in mouse macrophages. The role of the $\mathrm{p} 38$ and ERK1/2 in IL-17A-induced TNF- $\alpha$, IL- 6 and IL-1 $\beta$ secretion was also investigated by employing specific inhibitors. Addition of SB203580, the inhibitor of p38, 
blunted the three cytokines production induced by IL-17A, indicating that p38 activation was involved in the cytokine responses to IL-17A. U0126 is a specific inhibitor of MEK1/2 which is the kinase directly upstream to ERK1/2 [32]. U0126 caused a significant decrease in the IL-17 induced cytokines secretion. Thus we concluded that ERK1/2 also participates in the TNF- $\alpha$, IL- 6 and IL- $1 \beta$ secretion induced by IL-17A in mouse macrophage. In support of our data, Cortez et al found that IL-17 stimulates C-reactive protein expression via p38 and ERK1/2 in hepatocytes and coronary artery smooth muscle cells [33], and p38 MAPK signaling and the implication of NF- $\mathrm{kb}$ and AP1 were also demonstrated in previous studies in the field of IL-17 biology [15, 34].

Many cytokine-inducible responses are mediated by DNA-binding proteins such as NF$\kappa \mathrm{B}$ and AP-1 $[35,36]$. The promoter regions of the TNF- $\alpha$, IL- 6 and IL- $1 \beta$ genes have been shown to include putative NF- $\kappa B$ and AP-1 binding motifs [37]. We detected the activation of NF- $\mathrm{KB}$ and AP-1 following IL-17A stimulation in macrophages. Further, inhibition of NF$\kappa \mathrm{B}$ or AP-1 partly abolished IL-17A-induced TNF- $\alpha$, IL- 6 and IL- $1 \beta$ production. These data suggest that activation of transcription factors NF- $\kappa B$ and AP-1 may be involved in IL-17Ainduced TNF- $\alpha$, IL- 6 and IL- $1 \beta$ production in macrophages.

In conclusion, the central discovery of our study is that IL-17A prompted a proinflammatory macrophages phenotype characterized by enhanced production of TNF- $\alpha$, IL$1 \beta$, and IL-6. The effect of IL-17A on macrophages involved the activation of ERK1/2, p38, NF- $\kappa \mathrm{B}$ and AP-1 signaling pathways. Further, signaling inhibitor experiments demonstrated differential roles for these pathways in the cytokine response of macrophages to IL-17A.

\section{Abbreviations}

IL-17 RA (interleukin-17 receptor A); IL-17 RC (interleukin-17 receptor C); TNF- $\alpha$ (tumor necrosis factor- $\alpha$ ); IL-1 $\beta$ (interleukin-1 $\beta$ ); IL-6 (interleukin 6); MCP-1 (monocyte chemotactic protein-1); GM-CSF (granulocyte-macrophage colony stimulating factor); MMP2 (matrix metalloproteinase-2); IL-23p19 (interleukin-23p19); IFN- $\gamma$ (interferon- $\gamma$ ); GAPDH (glyceraldehyde-3-phosphate dehydrogenase).

\section{Conflict of Interest}

The authors declare no conflicts of interest.

\section{Acknowledgements}

This work was supported by grants from National Basic Research Program of China [973 Program: 2013CB531103 and 2012CB517805 to XC], National Natural Science Foundation of China [No. 81170303 and 81222002 to XC] and Program for New Century Excellent Talents in University of China [NCET-09-0380 to XC].

\section{References}

1 Libby P: Inflammation in atherosclerosis. Nature 2002;420:868-874.

2 Weber C, Zernecke A, Libby P: The multifaceted contributions of leukocyte subsets to atherosclerosis: Lessons from mouse models. Nat Rev Immunol 2008;8:802-815.

-3 Halvorsen B, Otterdal K, Dahl TB, Skjelland M, Gullestad L, Oie E, Aukrust P: Atherosclerotic plaque stability--what determines the fate of a plaque? Prog Cardiovasc Dis 2008;51:183-194.

4 van den Berg WB, Miossec P: Il-17 as a future therapeutic target for rheumatoid arthritis. Nat Rev Rheumatol 2009;5:549-553. 


\section{Cellular Physiology $\quad$ Cell Physiol Biochem 2013;32:1265-1274 and Biochemistry \\ Chen et al.: IL-17A and Macrophages}

5 Abraham C, Cho J: Interleukin-23/th17 pathways and inflammatory bowel disease. Inflamm Bowel Dis 2009;15:1090-1100.

6 Yuan J, Yu M, Lin QW, Cao AL, Yu X, Dong JH, Wang JP, Zhang JH, Wang M, Guo HP, Cheng X, Liao YH: Th17 cells contribute to viral replication in coxsackievirus b3-induced acute viral myocarditis. J Immunol 2010;185:4004-4010.

7 Liao YH, Xia N, Zhou SF, Tang TT, Yan XX, Lv BJ, Nie SF, Wang J, Iwakura Y, Xiao H, Yuan J, Jevallee H, Wei F, Shi GP, Cheng X: Interleukin-17a contributes to myocardial ischemia/reperfusion injury by regulating cardiomyocyte apoptosis and neutrophil infiltration. J Am Coll Cardiol 2012;59:420-429. Chen Z, O'Shea JJ: Th17 cells: A new fate for differentiating helper t cells. Immunol Res 2008;41:87-102. Iwakura Y, Ishigame H, Saijo S, Nakae S: Functional specialization of interleukin-17 family members. Immunity 2011;34:149-162.

10 Cheng X, Yu X, Ding YJ, Fu QQ Xie JJ, Tang TT, Yao R, Chen Y, Liao YH: The th17/treg imbalance in patients with acute coronary syndrome. Clin Immunol 2008;127:89-97.

11 Eid RE, Rao DA, Zhou J, Lo SF, Ranjbaran H, Gallo A, Sokol SI, Pfau S, Pober JS, Tellides G: Interleukin-17 and interferon-gamma are produced concomitantly by human coronary artery-infiltrating t cells and act synergistically on vascular smooth muscle cells. Circulation 2009;119:1424-1432.

12 Madhur MS, Funt SA, Li L, Vinh A, Chen W, Lob HE, Iwakura Y, Blinder Y, Rahman A, Quyyumi AA, Harrison DG: Role of interleukin 17 in inflammation, atherosclerosis, and vascular function in apolipoprotein e-deficient mice. Arterioscler Thromb Vasc Biol 2011;31:1565-1572.

13 Boyle JJ: Macrophage activation in atherosclerosis: Pathogenesis and pharmacology of plaque rupture. Curr Vasc Pharmacol 2005;3:63-68.

14 Kitami S, Tanaka H, Kawato T, Tanabe N, Katono-Tani T, Zhang F, Suzuki N, Yonehara Y, Maeno M: Il-17a suppresses the expression of bone resorption-related proteinases and osteoclast differentiation via il-17ra or il-17rc receptors in raw264.7 cells. Biochimie 2010;92:398-404.

15 Shahrara S, Pickens SR, Dorfleutner A, Pope RM: Il-17 induces monocyte migration in rheumatoid arthritis. J Immunol 2009;182:3884-3891.

16 Galkina E, Ley K: Immune and inflammatory mechanisms of atherosclerosis ${ }^{*}$ ). Annu Rev Immunol 2009;27:165-197.

17 Taleb S, Tedgui A, Mallat Z: Adaptive t cell immune responses and atherogenesis. Curr Opin Pharmacol 2010;10:197-202.

18 Zhou X, Nicoletti A, Elhage R, Hansson GK: Transfer of cd4(+) t cells aggravates atherosclerosis in immunodeficient apolipoprotein e knockout mice. Circulation 2000;102:2919-2922.

19 Zhou X, Robertson AK, Hjerpe C, Hansson GK: Adoptive transfer of cd4+ t cells reactive to modified lowdensity lipoprotein aggravates atherosclerosis. Arterioscler Thromb Vasc Biol 2006;26:864-870.

20 Lahoute C, Herbin 0, Mallat Z, Tedgui A: Adaptive immunity in atherosclerosis: Mechanisms and future therapeutic targets. Nat Rev Cardiol 2011;8:348-358.

21 Xie JJ, Wang J, Tang TT, Chen J, Gao XL, Yuan J, Zhou ZH, Liao MY, Yao R, Yu X, Wang D, Cheng Y, Liao $\mathrm{YH}$, Cheng X: The th17/treg functional imbalance during atherogenesis in apoe(-/-) mice. Cytokine 2010;49:185-193.

-22 Pejnovic N, Vratimos A, Lee SH, Popadic D, Takeda K, Akira S, Chan WL: Increased atherosclerotic lesions and th17 in interleukin-18 deficient apolipoprotein e-knockout mice fed high-fat diet. Mol Immunol 2009; $47: 37-45$.

23 Smith E, Prasad KM, Butcher M, Dobrian A, Kolls JK, Ley K, Galkina E: Blockade of interleukin-17a results in reduced atherosclerosis in apolipoprotein e-deficient mice. Circulation 2010;121:1746-1755.

24 van Es T, van Puijvelde GH, Ramos OH, Segers FM, Joosten LA, van den Berg WB, Michon IM, de Vos P, van Berkel TJ, Kuiper J: Attenuated atherosclerosis upon il-17r signaling disruption in ldlr deficient mice. Biochem Biophys Res Commun 2009;388:261-265.

-25 Erbel C, Chen L, Bea F, Wangler S, Celik S, Lasitschka F, Wang Y, Bockler D, Katus HA, Dengler TJ: Inhibition of il-17a attenuates atherosclerotic lesion development in apoe-deficient mice. J Immunol 2009;183:81678175.

26 Cheng X, Taleb S, Wang J, Tang TT, Chen J, Gao XL, Yao R, Xie JJ, Yu X, Xia N, Yan XX, Nie SF, Liao MY, Cheng Y, Mallat Z, Liao YH: Inhibition of il-17a in atherosclerosis. Atherosclerosis 2011;215:471-474. 


\begin{tabular}{|c|c|c|}
\hline \multirow{2}{*}{$\begin{array}{l}\text { Cellular Physiology } \\
\text { and Biochemistry }\end{array}$} & \\
\hline & $\begin{array}{l}\text { DoI: } 10.1159 / 000354525 \\
\text { Published online: November 21, } 2013\end{array}$ & $\begin{array}{l}\text { o } 2013 \text { S. Karger AG, Basel } \\
\text { www.karger.com/cpb }\end{array}$ \\
\hline
\end{tabular}

27 Taleb S, Romain M, Ramkhelawon B, Uyttenhove C, Pasterkamp G, Herbin O, Esposito B, Perez N, Yasukawa H, Van Snick J, Yoshimura A, Tedgui A, Mallat Z: Loss of socs3 expression in t cells reveals a regulatory role for interleukin-17 in atherosclerosis. J Exp Med 2009;206:2067-2077.

28 Swirski FK, Weissleder R, Pittet MJ: Heterogeneous in vivo behavior of monocyte subsets in atherosclerosis. Arterioscler Thromb Vasc Biol 2009;29:1424-1432.

29 Jovanovic DV, Di Battista JA, Martel-Pelletier J, Jolicoeur FC, He Y, Zhang M, Mineau F, Pelletier JP: Il-17 stimulates the production and expression of proinflammatory cytokines, il-beta and tnf-alpha, by human macrophages. J Immunol 1998;160:3513-3521.

- 30 Barin JG, Baldeviano GC, Talor MV, Wu L, Ong S, Quader F, Chen P, Zheng D, Caturegli P, Rose NR, Cihakova D: Macrophages participate in il-17-mediated inflammation. Eur J Immunol 2012;42:726-736.

-31 Kaminska B: Mapk signalling pathways as molecular targets for anti-inflammatory therapy--from molecular mechanisms to therapeutic benefits. Biochim Biophys Acta 2005;1754:253-262.

32 Favata MF, Horiuchi KY, Manos EJ, Daulerio AJ, Stradley DA, Feeser WS, Van Dyk DE, Pitts WJ, Earl RA, Hobbs F, Copeland RA, Magolda RL, Scherle PA, Trzaskos JM: Identification of a novel inhibitor of mitogenactivated protein kinase kinase. J Biol Chem 1998;273:18623-18632.

33 Patel DN, King CA, Bailey SR, Holt JW, Venkatachalam K, Agrawal A, Valente AJ, Chandrasekar B: Interleukin-17 stimulates c-reactive protein expression in hepatocytes and smooth muscle cells via p38 mapk and erk1/2-dependent nf-kappab and c/ebpbeta activation. J Biol Chem 2007;282:27229-27238.

-34 Shen F, Hu Z, Goswami J, Gaffen SL: Identification of common transcriptional regulatory elements in interleukin-17 target genes. J Biol Chem 2006;281:24138-24148.

-35 Xanthoulea S, Curfs DM, Hofker MH, de Winther MP: Nuclear factor kappa b signaling in macrophage function and atherogenesis. Curr Opin Lipidol 2005;16:536-542.

-36 Schonthaler HB, Guinea-Viniegra J, Wagner EF: Targeting inflammation by modulating the jun/ap-1 pathway. Ann Rheum Dis 2011;70:1109-112.

- 37 Lu H, Wu JY, Kudo T, Ohno T, Graham DY, Yamaoka Y: Regulation of interleukin-6 promoter activation in gastric epithelial cells infected with helicobacter pylori. Mol Biol Cell 2005;16:4954-4966. 